\title{
E-GOVERNMENT SERVICES IN ROMANIAN CITIES: A LOOK FROM THE INSIDE
}

\author{
Nicolae Urs ${ }^{1}$
}

\begin{abstract}
How good the e-government services of local governments are is usually ascertained through their success in attracting users. This paper looks at the other part of the equation. Our research aims to find out how successful the implementation of e-government services in Romanian local government is in the eyes of those tasked with rolling out these services.

As such, we surveyed heads of IT departments in the largest city halls in Romania (the county seats and the capital, Bucharest) to see how their IT professionals implemented e-government services and what their opinion was on E-government progress at a national level. We found that eService development was not a priority for Romanian city halls and that, with one exception, e-government did not appear prominently in their strategic development plans.
\end{abstract}

Key words: e-government, local government, public servants view, Romania.

\section{Introduction}

Researchers generally agree that e-government is becoming more and more important in facilitating interactions between the citizens and companies, on the one hand, and public institutions, on the other. But the gamut of opinion on the success of this implementation varies widely, from sceptics that say that e-government failed [14], to researchers that see a more incremental development of eServices, to optimists that talk about the imminent transformation of public administration by the forces of technology [9].

For those interested in the subject, there are various studies on the effects of e-government solutions or on the evaluation of technologies involved in implementing them. Usually, these studies focus on the e-government development stage [10], because it is easier and more straightforward to evaluate. And there is something inherently appealing about rankings: we seem to crave to see who is first, who is last and what are the causes for this, in a neatly packed chart.

Another type of e-government studies deals with user satisfaction with the online services offerings, both at local and at central levels. This kind of research is less prevalent, but it is nonetheless essential, because not involving the final beneficiaries can lead to poor design and low adoption rate, which can have a subversive effect, reinforcing the views of those that view e-government as just a fad or a resource hog. [3, 4 and 16].

The actors involved in e-government are usually thought of as public institutions, on the one hand, and citizens or companies, on the other. The problem with this interpretation is that we fail to take into consideration that those that design, implement, run, troubleshoot and expand those online

\footnotetext{
${ }^{1}$ College of Political, Administrative and Communication Scciences, BBU, Cluj-Napoca, 85 Minerilor Street, ClujNapoca,urs@fspac.ro
} 
services are also people: the IT specialists of public institutions. Their view on e-government development, with a few exceptions [1] is largely missing from the body of studies on this subject.

Related studies show that the competence of public servants directly affects the public administration performance [5]. Without a well-trained working force, even the best laid egovernment strategies often go awry. Regarding the attitudes of citizens and public servants about e-government implementation (pace, advantages and disadvantages, risks and rewards), some researchers suggested that they did not coincide [11]. Moreover, they stated that there were deep variances between different parts of the public (those who regularly use the internet, those who have interacted with the government online, those who were more technologically averse, etc.) or between different segments of the public employees (those in management positions, IT specialists, those who worked with e-government services, etc.). Moreover, studies show that IT specialists in Public Administration can decide or influence the direction in which e-government development is heading in their institution [13].

Romania has little academic literature on the topic of e-government to begin with, and we could find no studies that took the public servants directly involved in e-government operation into consideration. Our research represents a starting point in this direction.

From our experience, the IT departments in Romanian public institutions are under-dimensioned and understaffed. Keeping up with technology advancements, devising and implementing a longterm e-government strategy, allocating sufficient resources (personnel, money, time, authority) does not usually seem to be one of the priorities of central or local public institutions. Again, from our involvement in projects with local public administration from all over Romania, big cities face different problems than small ones (in big cities public institutions find it very hard to recruit and keep good people in the face of private competition, mainly because the pay is much lower in the public sector; in small cities, there is lack of people with specialized knowledge, who usually move to bigger cities, where there are higher chances of finding a good job) but the end result is the same: difficulties in filling even the small number of posts that Romanian public institutions allocate for IT departments.

We began this study trying to prove or disprove a series of hypotheses:

1. Romanian public institutions (in our case, City Halls) experience difficulties in filling IT positions;

2. Management support and internal reorganization of the institution are seen by the IT professionals as very important in e-government development;

3. The main obstacles in e-government development are lack of interinstitutional interoperability and the differences between pay in private versus public organizations;

4. City Halls face slow citizen adoption of existing online services.

We started with 48 municipalities in Romania (the county seats City Halls, plus the Bucharest General City Hall and those of the six sectors of our capital city). We tried to talk on the phone with the head of the IT department in each City Hall about their responsibilities, resources, and grievances, and asked them to fill out an online questionnaire (this was followed in some cases by 
further phone calls, to clarify some answers). With this tool, we tried to find out a number of things, such as:

- How well staffed their department was;

- What their evaluation of the e-government development stage was, both at a national level, and in their city;

- What the online services offered to citizens or companies were and what their uptake level was;

- What the main obstacles or drivers of e-government development in their city were.

In the end, we got 3 flat-out refusals (Bistrița, Constanța, Timișoara; they motivated these refusals by saying that their workload did now allow them the time). We could not talk with 8 heads of IT departments, for a number of reasons (their websites were down or we could not find them Călărași and Buftea, some public servants were on sick-leave, some did not answer the phone; there were cases where we could not get a hold of anyone from the City Hall and the website did not mention any direct phone number).

We were left with 37 promises to fill out our online survey. In the end we got 21 usable answers (a completion rate of $56.7 \%$ ). From this relatively low number of responses, we cannot propose general conclusions on the views of IT professionals in the Romanian local government, but we can start to see some patterns which will be verified in subsequent studies.

Drawing from some of our previous research [15], we also wanted to find out if IT department heads from City Halls which scored higher in our evaluation of e-government offerings differed in their thinking from those from cities that were placed lower on our ranking.

\section{Results}

The 21 cities from which we received responses are Bucharest Sector 6 (population 367,760), Bucharest Sector 2 (345,370), Cluj-Napoca (324.600), Brașov $(253,200)$, Bucharest Sector 1 (225,400), Ploiești (209,945), Pitești (155,383), Bacău (144,307), Tîrgu Mureș $(134,290)$, Baia Mare $(123,700)$, Buzău $(115,500)$, Satu Mare $(102,400)$, Râmnicu Vâlcea $(98,776)$, Drobeta Turnu Severin (92,600), Focşani (79,300), Tulcea $(73,707)$, Reșiţa $(73,282)$, Alba Iulia $(63,500)$, Deva $(61,123)$, Zalău $(56,200)$, Slobozia $(45,891)$. For Romania, and thinking of our focus on county seats, we have large, medium, and small cities in our dataset.

Most of our respondents were male (57 percent) and, surprisingly for this domain, most of them were over 40 years of age (in fact we had only four respondents under 40 years of age). This can probably be explained by the difficulties City Halls in Romania have in attracting and retaining young IT specialists. Most of them (55 percent) did not work in a private IT company before coming to a public institution. Half of them use internet banking or buy online once a week or more often. $25 \%$ of them use the internet for conducting banking operations or for purchasing from online stores less than once a month. 
A small majority $(62 \%)$ consider e-government development urgent or very urgent for their institution. They also have a better opinion of their City Hall online services offering: only 2 of them rated their city development level lower than the national level.

All cities offer the opportunity for citizens to pay their taxes online. Some other services offered online were complaints and requests (81\%) payment of fines (67\%), and asking for public interest information (57\%).

We wanted to know whether the city hall had any data on their intended customers; we asked if there were surveys or any other information about internet use in general and the profile of the internet user in their cities, or on their needs and expectations. We got only one response to this question (Bucharest Sector 2 has studies that show that $86 \%$ of its residents use the internet). This fact makes us think that, at least for the cities in question, online service development is strictly a top-down approach, where the management and the IT specialists inside the public institution decide what the e-government strategy is, with either minimal consultation of citizens or none at all. This is evident from the questionnaire responses also, where lack of public pressure scored low on the list of e-government development obstacles. Moreover, aside from Cluj-Napoca and, partially, Deva (which has a list of ITC objectives without explaining how they will be reached), no City Hall has, as part of its Development Strategy, a plan for coping with technological changes, a roadmap for implementing e-government solutions and an understanding of what this implies (full disclosure: the author of this study was one of the coordinators of the IT and E-government chapter of the ClujNapoca 2014-2020 Development Strategy); on the Tîrgu Mureș City Hall site we found links to Digital Mureș, some kind of ITC strategy, but we could not find any documents or news about this project. In most cases, e-government is not even mentioned, and when it appears, it is brought up in passing only, as a theoretical objective, without a clear plan, resource allocation or apparent comprehension of the changes involved.

Two of the hypotheses we started with were confirmed by the responses we gathered. For the other two, the results were more nuanced than a simple yes or no.

First hypothesis: Romanian public institutions (in our case, City Halls) experience difficulties in filling IT positions.

This was confirmed by the results of the questionnaire. $90 \%$ of respondents said that having good professionals in the IT department was either important or very important for creating and implementing online services. Only $28 \%$ of City Halls were able to fill the available positions assigned to their IT department (also a small number to begin with). $75 \%$ opined that lack of trained employees was either a big or very big obstacle in e-government development, while $75 \%$ said the same about the difficulties of offering an attractive pay package to good specialists. This was seen as an important problem, especially in big cities, where private companies are also looking to hire IT specialists, often as soon as they graduate. The monthly pay for an entry-level position in a private company located in a large Romanian city starts at 500-600 euros (with added benefits such as private health insurance and trainings on a variety of topics). In public institutions, the monthly pay starts at around 300 euro, and there are considerably fewer opportunities to earn promotions. In smaller cities, this competition for IT professionals with the private companies is not felt that acutely, but almost all respondents considered this a big or very big obstacle in their institution's egovernment development. Romanian academics (such as Dan Ioan Tufiş, an academician) have repeatedly said that to cover the needs of the IT sector, many more IT professionals were needed 
(the deficit is around 15.000-20.000 people, by most accounts, and growing, especially because big international companies still see Romania as an attractive place to relocate part of their business).

The next table shows the scores assigned by the respondents to the importance of the hurdles they encountered in developing online services for their institution (the scores are from 1 to 5 , one being the smallest obstacle). The most important impediments are the difficulty in keeping up with private sector offers in pay and other benefits, lack of adequate financial resources for their plans, shortage of qualified personnel, and lackluster support from the management.

\begin{tabular}{|l|l|l|l|l|l|l|}
\hline \begin{tabular}{|l|l|l|l|} 
Difficulty in competing on pay with private \\
companies
\end{tabular} & $\mathbf{1}$ & $\mathbf{2}$ & $\mathbf{4}$ & $\mathbf{5}$ & Average score \\
\hline Lack of financial resources & 1 & 0 & 4 & 6 & 9 & 4.10 \\
\hline & 1 & 0 & 5 & 7 & 7 & 3.95 \\
\hline Shortage of trained personnel & & & & 1 & & \\
\hline Absence of management support & 1 & 3 & 1 & 4 & 3.80 \\
\hline Lack of interinstitutional interoperability & 2 & 0 & 7 & 4 & 7 & 3.70 \\
\hline Lagging internal IT infrastructure & 0 & 3 & 8 & 4 & 5 & 3.55 \\
\hline Lack of openness and transparency & 1 & 2 & 8 & 6 & 3 & 3.40 \\
\hline Obsolete internal structure of the city hall & 2 & 4 & 4 & 6 & 4 & 3.30 \\
\hline Outdated internal procedures & 2 & 2 & 7 & 5 & 3 & 3.26 \\
\hline Lack of public pressure & 1 & 3 & 7 & 8 & 1 & 3.25 \\
\hline Lack of immediate results & 2 & 6 & 4 & 6 & 2 & 3.00 \\
\hline Slow internet connections & 3 & 2 & 9 & 4 & 2 & 3.00 \\
\hline
\end{tabular}

Table 1: The most important obstacles in implementing online services in Romanian public institutions

The second hypothesis we had was: Management support and internal reorganization of the institution are seen by the IT professionals as very important in e-government development.

To our surprise, the two items related to this subject in our question about the obstacles in implementing e-government (obsolete internal structure of the city hall, and outdated internal procedures) were in the bottom half of the results (with scores of 3.26 and 3.25, respectively). This can also be linked to the fact that the internal reorganization of the city hall was the last in the ranking of beneficial factors influencing the development of online services (2.95), while rethinking internal processes scored a little better (ninth out of twelve, with a score of 3.71).

This result can probably be explained by the fact that city halls in Romania have not undertaken radical reorganizations in the face of technological change. The IT departments in Romanian public institutions are usually on the bottom rungs of the organizational tree, lacking authority and resources to push for such a transformation. No city hall we studied has a position equivalent to a CIO (Chief Information Officer), and they are usually just a small bureau, part of a larger department. Our experience with public institutions tell us that the management usually sees IT specialists as the people that fix computers, clear out jammed printers and install Skype, rather than professionals who should devise digital strategies and implement e-government applications. As such, there is little surprise that support from management was the top scorer on the list of valuable influences for the success of the city hall online presence (4.48). 


\begin{tabular}{|l|r|r|r|r|r|r|}
\hline \multicolumn{1}{|l|}{} & $\mathbf{1}$ & $\mathbf{2}$ & $\mathbf{3}$ & $\mathbf{4}$ & $\mathbf{5}$ & Average score \\
\hline Management support & 0 & 0 & 3 & 5 & 13 & 4.48 \\
\hline Sufficient ITC equipment & 0 & 0 & 1 & 9 & 10 & 4.45 \\
\hline Sufficient financial resources & 0 & 0 & 1 & 9 & 10 & 4.45 \\
\hline Good relationships with ITC and digital solutions providers & 0 & 1 & 2 & 9 & 9 & 4.24 \\
\hline Well-trained people in the IT department & 1 & 0 & 1 & 10 & 8 & 4.20 \\
\hline Legal constraints & 0 & 0 & 3 & 10 & 7 & 4.20 \\
\hline Citizen's increasing usage of private online services & 0 & 1 & 3 & 11 & 6 & 4.05 \\
\hline Obtaining visible results fast & 0 & 2 & 3 & 11 & 4 & 3.85 \\
\hline Rethinking internal processes & 0 & 2 & 6 & 9 & 4 & 3.71 \\
\hline Ties with other public institutions & 0 & 3 & 5 & 10 & 3 & 3.62 \\
\hline Pressure from the public & 0 & 3 & 5 & 11 & 2 & 3.57 \\
\hline Internal reorganization of the city hall & 3 & 4 & 6 & 7 & 1 & 2.95 \\
\hline
\end{tabular}

Table 2: The most important beneficial factors helping online services implementation

With very few exceptions, city halls in Romania are still stuck in the bureaucratic or, at best, in the New Public Management paradigm of doing business. A combination of lack of resources (people, money, and authority), almost nonexistent interoperability, and deficiencies in internal digitalization led to a lag in conceptualizing and internalizing new organizational models, that put a bigger emphasis on the effects of technology progress and the changes it brings - for example, the DEG (Digital-Era Governance) theory proposed by Dunleavy et al. [6]. Without this theoretical foundation, it is hard to envision rapid change in digital governance in Romanian cities (which should include internal reorganizations, digital-first processes, boosting IT spending, and fighting for the best IT specialists) for the foreseeable future.

Our third hypothesis - the main obstacles in e-government development are lack of interinstitutional interoperability and the differences between pay in private versus public organizations - was also partially disproved.

True, especially in big cities, the difference in pay and other perks between what the public institutions can offer and what the private companies are prepared to put on the table in the race to hire the best IT specialists is the biggest hurdle our respondents identified. But the second item we looked upon (deficiencies in information sharing between public institutions) did not score as high as we would have expected (3.55).

A lot of interactions between companies and citizens, on one hand, and the state, on the other, involve more than one institution. Without robust interinstitutional data links and procedures, these services are not suitable to be moved entirely online (it is infamous and also something of a joke in Romania that the city hall usually asks for a copy of your ID for any interaction with citizens, even though the Local Register Office is part of the Local Council, which is itself part of the city hall).

It is telling that the only institution with which more than 1 city hall has agreements of data exchange (the way this exchange is made, the types of data shared, the ways in which discrepancies are resolved, etc. could be the subject of another research) is the National Agency for Fiscal Administration (NAFA) - 33\% of respondents said that their institution had some kind of data sharing with NAFA. Other than that, no other public or private organization was mentioned more than once, and most cities have no such sharing agreements at all. This deficiency is all the more 
glaring if we remember that the city halls comprised in the study are some of the biggest in Romania. It is true that a lot of other countries face problems when it comes to linking together IT systems that were not envisioned to talk to each other [8]. Small advances in this field are starting to appear, but usually the approach is top-down, from the central government, through legislative instruments and coercion.

Another element evident from our data is that there is very little public pressure to introduce more and better public eServices. As you can see from the charts above, lack of public pressure was third from the bottom on the list of obstacles in developing e-government services (in other words, the respondents did not consider this important). This is also apparent from the list of beneficial influences for their work, where the same public clamoring for progress in this field ranked second to last.

More collaboration between institutions in information exchange, database linking and designing seamless services across both internal departments and public institutions is fraught by multiple problems, both local and national. An universal e-ID of some sorts is very problematic to introduce, for a number of reasons (socio-cultural - a lot of Romanians protest this on religious reasons, historical - most Romanians still remember communist times, when state surveillance was used not to provide better services, but for other, less desirable, reasons entirely, technical - most IT systems were not created with interconnectivity in mind, financial - e-government was never a priority to the Government, irrespective of bombastic announcements, security - citizens are more and more aware of the possibility of data breaches, with a number of those featured prominently in massmedia). Without this underpinning, unified eServices are much harder to implement (success stories such as Estonia are partially based on effective universal electronic identification).

Our forth hypothesis was that City Halls face slow citizen adoption of existing online services. This was largely confirmed, with the caveat that we have little data to support a generalization, for a number of reasons.

First of all, only 12 out of the 21 respondents specified any hard numbers for the usage of online services. Secondly, in the case of one of the most important and wildly used (relatively speaking) service - Online tax payments - some citizens could have used a central government site, ghiseul.ro, which provides such services for any enrolled municipality (all city halls in our study were registered). Our efforts to obtain these data from the site administrators failed until now (if we can get a hold of the information, we will update the article at that time).

Generally, the adoption figures were low. Even if all city halls offer the possibility for online tax payments, the numbers were at most in the thousands, (Bucharest Sector 2 was topped the chart with 9021 citizens paying online, followed by Sector 1 (6560) and Cluj-Napoca (5297).

If we take into account the city population, Baia Mare emerges victorious, with a little over $4 \%$ of citizen paying their taxes online in the first 11 months of 2016. For fine payments, Bucharest Sector 1 takes the first place, followed closely by Baia Mare. For the other categories we had too few data for a meaningful comparison. 


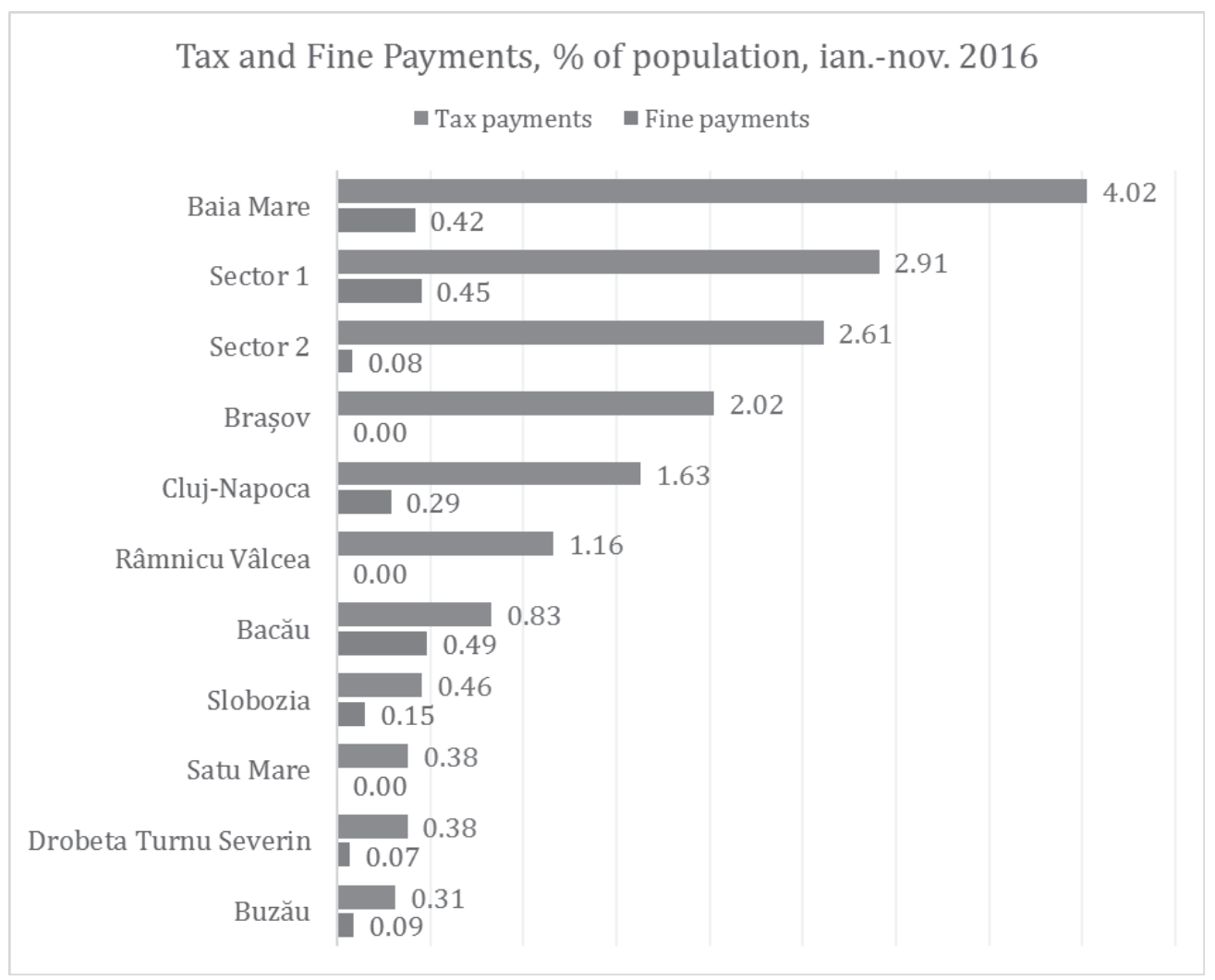

Table 3. Percentage of people using online payment of taxes or fines

It is hard to compare these findings with data from other countries, due to the paucity of studies regarding local tax payments through the internet. We consider these figures as proof of low uptake rates in Romanian cities because no city hall can present a rate of 5\% or more of tax fillings done online and because the instruments to pay online are easy to use and understand (a lot of Romanians pay online or conduct banking operations online; a 2015 study by iSense Solutions showed that $53 \%$ of Romanians living in cities have bought goods or services online, paying with debit or credit cards). Another reason is that these instruments have been available for some years, especially on big cities websites.

One reason for the low adoption rate can be insufficient public knowledge about the possibility to pay your taxes or fines online. Due to the low priority given to e-government in general by Romanian city halls, it comes as no surprise that advertising these eServices is typically confined to an announcement or a banner on official websites, while citizens do not routinely interact with public authorities online - according to Eurostat, only 9\% of Romanians do [7].

Another reason could be the relatively low level of trust Romanians have in public institutions. A study of INSCOP [2] shows that $37.3 \%$ of citizens trust their city hall (for comparison, the Parliament enjoys the trust of $12.6 \%$ of respondents, while the presidency tops the ranking, with $45.2 \%)$. 


\section{Other findings}

The first signs of collaboration between public and private institutions in the field of e-government are beginning to appear. In Braşov, for example, the city hall and public utilities and telecom companies (among these, some are public and some are private) are starting to exchange geospatial data, to better coordinate their interventions and network expansions.

One of our curiosities was finding out if those respondents with work experience in private IT companies saw e-government development somewhat differently than those without. $45 \%$ of the IT specialists in our study had previous private work experience, and they tended to view the state of national e-government development more critically (an average score of 2.56, on a 1-5 scale, where 5 was the biggest score). Those that had only public sector experiences gave an average score of 2.86 to Romanian e-government efforts. Regarding their opinion on their own public institution egovernment progress, the scores were equal, both categories settling for a middle-of-the-road 3. Another interest was seeing how the scores of our previous research (evaluating the online offerings of the Romanian County Seats) correlated with the IT managers' own perception about how well their city hall was doing on the e-services front.

\begin{tabular}{|c|c|c|}
\hline & $\begin{array}{r}\text { E-government } \\
\text { score }\end{array}$ & $\begin{array}{r}\text { City Hall e-gov development } \\
\text { auto evaluation (1-5) }\end{array}$ \\
\hline Alba Iulia & 68.61 & 4 \\
\hline Baia Mare & 60.95 & 4 \\
\hline Satu Mare & 59.35 & 3 \\
\hline Sector 6 & 55.89 & 2 \\
\hline Tîrgu Mureș & 53.35 & 4 \\
\hline Cluj-Napoca & 50.99 & 2 \\
\hline Zalău & 49.12 & 2 \\
\hline Deva & 46.12 & 3 \\
\hline Pitești & 45.35 & 3 \\
\hline Brașov & 44.96 & 4 \\
\hline Ploiești & 43.57 & 3 \\
\hline Focșani & 41.40 & 3 \\
\hline Bacău & 40.93 & 4 \\
\hline Sector 2 & 35.11 & 3 \\
\hline Râmnicu Vâlcea & 34.16 & 3 \\
\hline Buzău & 32.68 & 3 \\
\hline Drobeta Turnu & & \\
\hline Severin & 32.42 & 2 \\
\hline Sector 1 & 31.65 & 2 \\
\hline Reșița & 27.23 & 3 \\
\hline Tulcea & 24.64 & 3 \\
\hline Slobozia & 22.76 & 3 \\
\hline
\end{tabular}

Table 4: Correlation between the auto-evaluation of e-gov development stage and the actual ranking 


\section{Limits of the study and further research}

As mentioned previously, the number of respondents is relatively low. Another limit of the research is the limited insights gathered from the online questionnaire. Face-to-face interviews with at least some of the respondents could bring a more in-depth understanding of the IT professionals working in Romanian public institutions, and this will probably be the subject of one of my future studies.

The study could be enriched by data from other public institutions or organizations, as well as by information on public services intermediated by central government sites (ghiseul.ro is a case in point).

This type of research could be performed within a multinational comparative project, so as to understand differences and similarities between countries and gather best practices.

\section{Conclusion}

The main takeaway from this study is an understanding of the low priority e-government development has in the biggest city halls in Romania. From the small number of employees in IT departments, the little importance given to the IT units in general, the low number of online services offered and the disappointing uptake from the citizens, to the lack of visible strategies for eServices, all elements point to haphazard and uncoordinated efforts to digitalize Romanian public institutions. IT professionals are by and large aware of the problems, if, on average, a little behind in keeping up with the latest theoretical developments. Without more resources invested in all facets of egovernment (new technology, more people, better training, better collaboration with private stakeholders, and more authority to shake things up inside the institutions), the road towards more and better online services will be slow and arduous, with many detours and walk backs. All-in-all, in the face of so many obstacles, we think that the IT specialists in Romanian city halls are doing a better job than we expected.

\section{References}

[1] BALDWIN, J. N., GAULD, R., and GOLDFINCH, S.: What Public Servants Really Think of E-Government. Public Management Review, 14(1), 2012, p.105-127.

[2] Barometrul INSCOP - Adevărul despre România, March 2016. (2017, January 5). Retrieved from INSCOP: http://www.inscop.ro/aprilie-2016-increderea-in-institutii.

[3] BOVENS, M., and ZOURIDIS, S.: From street-level to system-level bureaucracies: How information and communication technology is transforming administrative discretion and constitutional control. Public Administration Review, 62 (2), 2002, p.174-84.

[4] CHAN, F. K. Y., THONG, J. Y. L., VENKATESH, V., BROWN, S. A., HU, P. J., and TAM, K. Y.: Modeling citizen satisfaction with mandatory adoption of an e-government technology. Journal of the Association for Information Systems, 11(10), 2010, p.519-549.

[5] CHUNG, H. Y., LEE, G. G., and KUO, R. Z.: Determinants of Public Servants' Intention to Adopt E-Government Learning. Review of Public Personnel Administration, 36(4), 2015, p.396-411. 
[6] DUnleavy, P., MARGetTS, H., BASTOW, S., and TINKLER, J.: New Public Management Is Dead-Long Live Digital-Era Governance, Journal of Public Administration Research and Theory, 16, 2005, p.467-494.

[7] Eurostat. (2017, January 5). E-government statistics, 2016. Retrieved from Eurostat: http://ec.europa.eu/eurostat/tgm/table.do?tab=table\&init=1\&language=en\&pcode=tin00012\& plugin $=1$.

[8] GATAUTIS, R, KULVIETIS, G, and VITKAUSKAITE, E,: Lithuanian eGovernment Interoperability Model. Inzinerine Ekonomika-Engineering Economics, 2, 2009, p.38-48.

[9] HAZLETT, S.-A., and HILL, F.: E-government: The realities of using IT to transform the public sector. Managing Service Quality, 13(6), 2003, p.445-452.

[10] HOLZER, M., ZHENG, Y., MANOHARAN, A., and SHARK, A.: Digital Governance in Municipalities Worldwide. Newark, New Jersey: E-Governance Institute, National Center for Public Performance, Rutgers University, 2014.

[11] MOON, M. J. and WELCH, E. W.: Same Bed, Different Dreams? A Comparative Analysis of Citizen and Bureaucrat Perspectives on E-Government. Review of Public Personnel Administration, 25(3), 2005, p.243-264.

[12] NORRIS, D. F., and REDDICK, C. G.: Local E-Government in the United States: Transformation or Incremental Change? Public Administration Review, 2013, p.165-175.

[13] ROSE, J., PERSSON, J. S., and HEEAGER, J. T.: How e-Government managers prioritise rival value positions: The efficiency imperative. Information Polity, 20, 2015, p.35-59.

[14] ȘANDOR, S. D.: ICT and Public Administration. Transylvanian Review of Administrative Sciences, 2012, p.155-164.

[15] URS, N.: Online Services and Social Media Use in Romanian Cities: Can We See a Pattern? 24th NISPAcee Annual Conference, Spreading Standards, Building Capacities: European Administrative Space in Progress, NISPAcee Press, 2016, p.1-17.

[16] WELCH, E. W., HINNANT, C. C., and MOON, M. J.: Linking citizen satisfaction with egovernment and trust in government. Journal of Public Administration Research and Theory, 15(3), 2005, p.371-391. 